\title{
Allometric Modelling of the Stem Carbon Content of Rhizophora mucronata in a Tropical Mangrove Ecosystem
}

\author{
W. M. Dimuthu Nilmini Wijeyaratne $(1)$ and Pawani Madhushani Liyanage \\ Department of Zoology and Environmental Management, Faculty of Science, University of Kelaniya, \\ Dalugama, Kelaniya, Sri Lanka \\ Correspondence should be addressed to W. M. Dimuthu Nilmini Wijeyaratne; dimuthu.wijeyaratne@kln.ac.lk
}

Received 17 April 2020; Revised 31 May 2020; Accepted 4 June 2020; Published 25 June 2020

Academic Editor: Ahmad A. Omar

Copyright (C) 2020 W. M. Dimuthu Nilmini Wijeyaratne and Pawani Madhushani Liyanage. This is an open access article distributed under the Creative Commons Attribution License, which permits unrestricted use, distribution, and reproduction in any medium, provided the original work is properly cited.

\begin{abstract}
Mangrove ecosystems are identified as important blue carbon ecosystems because they play an important role in carbon sequestration among the coastal ecosystems. The present study was conducted to develop an allometric model to determine the stem carbon content of Rhizophora mucronata in a conserved tropical mangrove ecosystem. The stepwise regression with backward elimination was used to identify the best fit model to predict the stem carbon content of Rhizophora mucronata. The allometric equation, $\operatorname{Ln} C=-2.403+2.247 \mathrm{Ln} \mathrm{DBH}$, where $C$ : stem carbon content and DBH: diameter at breast height, was constructed to be evaluated and validated as the most suitable and practically applicable model. The reliability of the model was $76.7 \%$, and the model was significant at 95\% level of significance. The model bias values and the model efficiency values for the best fit model suggested that the model is suitable to be used practically. The present study used a nondestructive method of measuring individual tree parameters to develop this allometric equation to predict the stem carbon content and it is considered as an environmentally friendly approach with minimum damage to the tree.
\end{abstract}

\section{Introduction}

Mangroves play an important role in carbon sequestration in tropical and subtropical coastal areas, and they have a considerable contribution of carbon dioxide mitigation. The mangrove forests are very diverse ecosystems and they consist of true mangroves, mangrove-associated plants, and other organisms [1]. Most mangrove forests are located in tropical areas, although there are some expansions into subtropical regions as well. The approximate global area covered by mangrove forests is estimated to be $140,000 \mathrm{~km}^{2}$ with the highest extent of mangroves occurring in Asia (42\%), followed by Africa (20\%) and North and Central America (15\%) [2]. The most common tropical mangrove genera include Avicennia, Rhizophora, Bruguiera, and Sonneratia. These genera are identified as most suitable species to be used in tropical mangrove replantation programmes due to their ability to distribute in a wide range of soil and hydrological conditions [3].
Rhizophora mucronata belongs to family Rhizophoraceae. This species is commonly known as the loop-root mangrove, red mangrove, and Asiatic mangrove $[4,5]$. This is a very common species in the mangrove forests in the Asian region and found in Cambodia, India, Indonesia, Malaysia Pakistan, Sri Lanka, Thailand, and Vietnam $[5,6]$.

Rhizophora mucronata has a developed strong root system, which can hold the sediments tightly, and thereby, they can serve as very important coastline stabilizers to protect the coastal ecosystems from strong storms, waves, and coastal erosion. Furthermore, they can act as barriers to the excess silt and sediments washed away into estuaries and lagoons and thereby prevent the harm to the coral reefs and sea grass beds due to excessive siltation [7-10]. Furthermore, Rhizophora mucronata is recognized as a species with a considerable economic importance as it provides natural products such as charcoal, wild honey, and timber, food, and medicinal element to the mangrove forest associated residents to improve the quality of their livelihoods $[9,10]$. 
In addition, Rhizophora mucronata is commonly used in the tropical mangrove replantation programmes due to its adaptability and rapid growth rate. When selecting mangrove species for replantation, the factors such as their adaptability, growth rate, and the extent of the root system are considered as high-priority characteristics. However, considering the current global warming conditions in the world, it is important to consider the carbon sequestration capacity of the selected species for replantation as the mangrove plants are considered to be excellent carbon dioxide removers from the atmosphere $[11,12]$.

Coastal ecosystems such as mangrove forests are identified as blue carbon ecosystems and they store more carbon per unit area than terrestrial forests and therefore are recognized as highly important ecosystems to mitigate climate change [12].

However, the carbon sequestration potential of Rhizophora mucronata is not widely researched in the tropical mangrove ecosystems. The studies that have been conducted so far have followed a destructive method of sampling, which involves the removal of sampled trees from the ecosystem and measuring the carbon content stored in the plant parts. However, the removal of plants from their natural ecosystem can have detrimental effects to the global climate and therefore currently it is not encouraged to remove plants even for the research purposes.

Therefore, the present study was conducted with the objective of using a nondestructive method to estimate the stem carbon content of Rhizophora mucronata in conserved tropical mangrove ecosystems.

\section{Methodology}

This study was conducted in a major mangrove conservation forest, The Kadol Kale mangrove forest located in Sri Lanka. Seventy individual trees of Rhizophora mucronata were selected from the study area based on purposive sampling. Damaged trees and trees devoid of leaves were not sampled during the study to avoid the effects on biomass accumulation process. A diameter tape was used to measure the diameter at breast height (DBH) of each tree, and the clinometer method was used to measure the total tree height, tree crown height, and merchantable stem height. The method described by Sabin was used to measure the stem volume of each plant [13]. ImageJ software was used to measure the leaf area of each tree (https://imagej.nih. gov/ij/).

2.1. Determination of the Stem Carbon Biomass. Increment borer was used to collect core samples of tree trunk from each tree at breast height with relatively minor injury to the tree. The Archimedes displacement principle was used to measure the initial volume of the collected core samples. The fixed stem carbon biomass of all the core samples was determined by loss on the ignition method as described by Guendehou and Leehtonen [14].

Considering the diameter at breast height of all the trees, the trees were grouped into classes as follows:

$$
\begin{aligned}
& \text { Diameter class } 1: 4.0<\mathrm{DBH} \leq 6.0 \mathrm{~cm} \\
& \text { Diameter class 2: } 6.0<\mathrm{DBH} \leq 8.0 \mathrm{~cm} \\
& \text { Diameter class 3: } 8.0<\mathrm{DBH} \leq 10.0 \mathrm{~cm} \\
& \text { Diameter class 4: } 10.0<\mathrm{DBH} \leq 12.0 \mathrm{~cm} \\
& \text { Diameter class 5: } 12.0<\mathrm{DBH} \leq 14.0 \mathrm{~cm} \\
& \text { Diameter class 6: } 14.0<\mathrm{DBH} \leq 16.0 \mathrm{~cm}
\end{aligned}
$$

Carbon sequestration performance at each diameter class was determined by calculating the mean stem carbon content at each diameter class. The percentage increase of mean stem carbon content compared to previous diameter class was also calculated.

The data were tested for normality using the Anderson Darling test, and the nonnormalized data were log transformed as appropriate. The correlation between the stem carbon content and the individual tree parameters was assessed using person's correlation analysis. The transformed data were used in model construction, evaluation, and validation.

\subsection{Construction Evaluation and Validation of the Allometric} Model. Stepwise regression with backward elimination was used to construct an allometric equation for the stem carbon content of Rhizophora mucronata. Only $75 \%$ of data were used in construction of the model while other $25 \%$ of data were used in model validation. The best fitted model was evaluated using quantitative and qualitative evaluation methods as described by Subasinghe and Haripriya [15]. The best fitted model was used to estimate the stem carbon content of reserved $25 \%$ of trees. The model was validated using the diagram between the actual values and the residual values and Student's $t$ test was used to compare the predicted stem carbon content from the allometric equation and the measured stem carbon content. MINITAB 14 software was used for statistical analysis.

\section{Results and Discussion}

The mean $\mathrm{DBH}$, stem height, merchantable stem height, crown height leaf area and the stem carbon content of Rhizophora mucronata are given in Table 1 . The diameter at breast height of the sampled trees ranged from $4.7 \mathrm{~cm}$ to 15 . $9 \mathrm{~cm}$. The total height ranged from $3.5 \mathrm{~m}$ to $12.1 \mathrm{~m}$. The merchantable stem height and crown height ranged from $2.3 \mathrm{~m}$ to $8.8 \mathrm{~m}$ and $0.5 \mathrm{~m}$ to $6.9 \mathrm{~m}$ respectively. The total leaf area of the sampled trees ranged from $1.7 \mathrm{~m}^{2}$ to $50.5 \mathrm{~m}^{2}$. The stem carbon content of the sampled trees ranged from $3.5 \mathrm{~kg}$ to $109.6 \mathrm{~kg}$ (Table 1 ).

The variations of stem carbon content at different $\mathrm{DBH}$ classes are given in Table 2. The mean stem carbon content at the lowest diameter class was significantly lower than the other diameter classes. The significantly highest stem carbon content was recorded from the Rhizophora mucronata trees at DBH class $5(12.1 \mathrm{~cm}-14.00 \mathrm{~cm})$. However, there was no significant difference in the mean stem carbon content of the trees at the $\mathrm{DBH}$ classes 4 and 6 . The highest percentage increase of mean stem carbon content was observed between the $\mathrm{DBH}$ classes 1 and 2. The percentage increase of mean 
TABle 1: The descriptive statistics of the tree parameters of Rhizophora mucronata.

\begin{tabular}{lc}
\hline Parameter & Mean \pm SD \\
\hline Diameter at breast height $(\mathrm{cm})$ & $9.1 \pm 2.6(4.7-15.9)$ \\
Total tree height $(\mathrm{m})$ & $8.1 \pm 2.0(3.5-12.1)$ \\
Merchantable stem height $(\mathrm{m})$ & $4.9 \pm 1.6(2.3-8.8)$ \\
Crown height $(\mathrm{m})$ & $3.1 \pm 1.3(0.5-6.9)$ \\
Leaf area $\left(\mathrm{m}^{2}\right)$ & $17.0 \pm 4.75(1.7-50.5)$ \\
Stem carbon content $(\mathrm{kg})$ & $52.3 \pm 2.5(3.5-109.6)$ \\
\hline
\end{tabular}

The data are presented as mean \pm standard deviation. The values within the parentheses indicate the range of each parameter.

stem carbon content decreased in the other successive DBH classes (Table 2). Generally, mature trees are expected to have long carbon residence time. However, there is no consensus on the contribution of old trees to carbon storage due to lack of long-term individual tree data [16]. Declining tree growth over time is caused due to changes in the supply rate of required resources (light, nutrients, and water), change in balance between photosynthesis and respiration, increased hydraulic resistance, decreased nutrient supply, or genetic changes with meristem age which can result in increased carbon storage capacity of the mature trees compared to the new trees [17-21].

The results of the correlation analysis are given in Table 3. The stem carbon content of Rhizophora mucronata showed significant positive correlations with $\mathrm{DBH}$ $\left(R^{2}=0.797, p \leq 0.001\right)$, total stem height $\left(R^{2}=0.648, \leq 0.001\right)$ and merchantable stem height $\left(R^{2}=0.697, \leq 0.001\right)$ (Table 3$)$.

3.1. Model Construction. Stepwise regression with backward elimination was used to identify the major predictors of stem carbon content of Rhizophora mucronata. To construct the model, $75 \%$ of data were used. The predictor variables used were DBH (diameter at breast height), total height, crown height, merchantable stem height, and leaf area. Two models (Model A and Model B) were constructed from the stepwise regression with backward elimination method:

Model A: Ln $C=-1.545-2.122$ Ln $\mathrm{TH}+2.020 \mathrm{Ln}$ $\mathrm{MSH}+0.874 \mathrm{Ln} \mathrm{CH}+2.011 \mathrm{Ln} \mathrm{DBH}$

Model B: Ln $C=-2.403+2.247$ Ln DBH

Here, $C$ : stem carbon content, TH: total height, MSH: merchantable stem height, $\mathrm{CH}$ : crown height, and $\mathrm{DBH}$ : diameter at breast height.

The constructed models, their regression coefficients, and VIFs (variance inflation factors) are given in Table 4. For Rhizophora mucronata $\mathrm{DBH}$, crown height, total height, and stem height $(p \leq 0.001)$ were statistically significant with stem carbon content. Leaf area was not statistically significant. In order to find whether the explanatory variables were related to each other, multicollinearity was checked. The VIF values were used to measure the effect of multicollinearity among the explanatory variables. The VIF $>5$ suggests that the regression coefficient is poorly estimated due to severe multicollinearity, and $1<\mathrm{VIF}<5$ suggests that regression coefficient is poorly estimated due to severe multicollinearity. The VIF $=1$ means that there is no multicollinearity among the explanatory variables, and therefore, these variables are best suited to fit into the model. In the model $\mathrm{A}$, total height $(\mathrm{VIF}=22.20)$, stem height $(\mathrm{VIF}=10.22)$, and crown height $(\mathrm{VIF}=9.75)$ indicate high multicollinearity. Therefore, total height, stem height, and crown height were eliminated to refit the model. In model B, DBH $($ VIF $=1)$ showed a good fit for the model $\left(R^{2}=76.7 \%\right)$ (Table 4). As it is always better to keep the model simple in the real-world application, the model B was selected as the best model for Rhizophora mucronata.

3.2. Evaluation of the Model. Model fit was examined using $p$ value, $R^{2}$ value, and residual diagram. The $p$ value of the best fit model for Rhizophora mucronata was statistically significant as it was lower than the alpha level of 0.01 (Table 4, stepwise regression analysis with backward elimination method). For the best fit model, the explanatory variable DBH was statistically significant and the high $R^{2}$ value of the best fit model indicated that the dependent variable which is the stem carbon content of Rhizophora mucronata can be explained up to high percentage (more than $60 \%$ ) by the selected explanatory variable, which is $\mathrm{DBH}$. The residual distribution diagrams for the best model for Rhizophora mucronata is given in Figure 1. Distribution of the residuals for the models indicated a random pattern, and the distribution were between +1 and 1 implying a good fit for linear model (Figure 1).

The model bias and modelling efficiency values for the best fitted model of Rhizophora mucronata was used for the evaluation of the model. The model bias value and the model efficiency values for Rhizophora mucronata were -0.002563323 and 0.7665 , respectively. The model bias value was very close to 0 , and the modelling efficiency value was close to one indicating that the selected model is well suited to predict the stem carbon content of Rhizophora mucronata.

3.3. Validation of the Model. The reserved $25 \%$ of data were used for model validation. The residuals values for Rhizophora mucronata were calculated as the difference between the actual stem carbon content and predicted stem carbon content from the model. The residual diagram of residual versus actual values for Rhizophora mucronata is given in Figure 2. The residual diagram showed a random pattern indicating that the model can be proved to use in the real world (Figure 2).

The mean values of the measured stem carbon content and the predicted stem carbon content using the prediction model for Rhizophora mucronata are given in Table 5. The measured stem carbon content of the Rhizophora mucronata trees used for model validation ranged from $1.3 \mathrm{~kg}$ to $4.3 \mathrm{~kg}$ and their predicted values ranged from $1.3 \mathrm{~kg}$ to $3.6 \mathrm{~kg}$. There was no significant difference of the mean measured stem carbon content and the mean predicted stem carbon content from the allometric equations developed for Rhizophora mucronata (Table 5, Student's $t$ test, $p>0.05$ ). 
TABLE 2: The stem carbon content of Rhizophora mucronata at different classes of diameter at breast height.

\begin{tabular}{lcc}
\hline $\begin{array}{l}\text { Diameter at breast height } \\
(\mathrm{cm})\end{array}$ & $\begin{array}{c}\text { Stem carbon content } \\
(\mathrm{kg})\end{array}$ & $\begin{array}{c}\text { Percentage increase of mean stem carbon content compared to previous diameter } \\
\text { class }(\%)\end{array}$ \\
\hline $4-6$ & $6.6 \pm 1.5^{\mathrm{a}}$ & - \\
$6.1-8.0$ & $17.2 \pm 3.5^{\mathrm{b}}$ & 160.6 \\
$8.1-10.0$ & $32.7 \pm 5.1^{\mathrm{c}}$ & 90.1 \\
$10.1-12.0$ & $52.5 \pm 7.4^{\mathrm{d}}$ & 60.6 \\
$12.1-14.0$ & $72.6 \pm 15.5^{\mathrm{e}}$ & 38.3 \\
$14.1-16.0$ & $53.5 \pm 10.2^{\mathrm{d}}$ & - \\
\hline
\end{tabular}

The stem carbon content data are presented as mean \pm standard deviation. The stem carbon content indicated by different superscript letters is significantly different from each other at $95 \%$ level of significance $(p<0.05)$.

TABLE 3: The correlation coefficient of Pearson's correlation analysis among the tree parameters of Rhizophora mucronata.

\begin{tabular}{|c|c|c|c|c|c|}
\hline & Total tree height & Merchantable stem height & Crown height & Leaf area & Stem carbon \\
\hline $\mathrm{DBH}$ & $\begin{array}{c}0.212 \\
(0.079)\end{array}$ & $\begin{array}{c}0.217 \\
(0.071)\end{array}$ & $\begin{array}{c}0.069 \\
(0.572)\end{array}$ & $\begin{array}{c}0.217 \\
(0.071)\end{array}$ & $\begin{array}{l}0.797^{*} \\
(0.000)\end{array}$ \\
\hline Total tree height & - & $\begin{array}{c}0.765^{*} \\
(0.000)\end{array}$ & $\begin{array}{c}0.638^{*} \\
(0.000)\end{array}$ & $\begin{array}{c}-0.147 \\
(0.224)\end{array}$ & $\begin{array}{l}0.648^{*} \\
(0.000)\end{array}$ \\
\hline Merchantable stem height & & - & $\begin{array}{c}-0.008 \\
(0.949)\end{array}$ & $\begin{array}{c}-0.141 \\
(0.244)\end{array}$ & $\begin{array}{l}0.697^{*} \\
(0.000)\end{array}$ \\
\hline Crown height & & & - & $\begin{array}{l}-0.060 \\
(0.623)\end{array}$ & $\begin{array}{c}0.025 \\
(0.836)\end{array}$ \\
\hline Leaf area & & & & - & $\begin{array}{c}0.131 \\
(0.351)\end{array}$ \\
\hline
\end{tabular}

Values within parentheses indicate the $p$ value. ${ }^{*}$ Significant correlations at $p \leq 0.001$.

TABLE 4: The $p$ values and VIF values of different tree parameters and $R^{2}$ values of each constructed models (Model A and Model B for Rhizophora mucronata).

\begin{tabular}{|c|c|c|c|}
\hline Tree parameter & $p$ & VIF & $R^{2}$ \\
\hline \multicolumn{4}{|c|}{$\begin{array}{l}\text { Model A: } \operatorname{Ln} C=-1.545-2.122 \operatorname{Ln} \mathrm{TH}+2.020 \mathrm{Ln} \mathrm{MSH}+0.874 \mathrm{Ln} \\
\mathrm{CH}+2.011 \mathrm{Ln} \mathrm{DBH}\end{array}$} \\
\hline $\begin{array}{l}\text { Merchantable stem height (MSH) } \\
\text { Crown height }(\mathrm{CH}) \\
\text { Diameter in breast height (DBH) }\end{array}$ & $\begin{array}{l}p \leq 0.001 \\
p \leq 0.001 \\
p \leq 0.001 \\
p \leq 0.001\end{array}$ & $\begin{array}{c}22.2 \\
10.22 \\
9.75 \\
1.10 \\
\end{array}$ & $92.4 \%$ \\
\hline \multicolumn{4}{|c|}{ Model B: Ln $C=-2.403+2.247$ Ln DBH } \\
\hline Diameter in breast height (DBH) & $p \leq 0.001$ & 1 & $76.7 \%$ \\
\hline
\end{tabular}

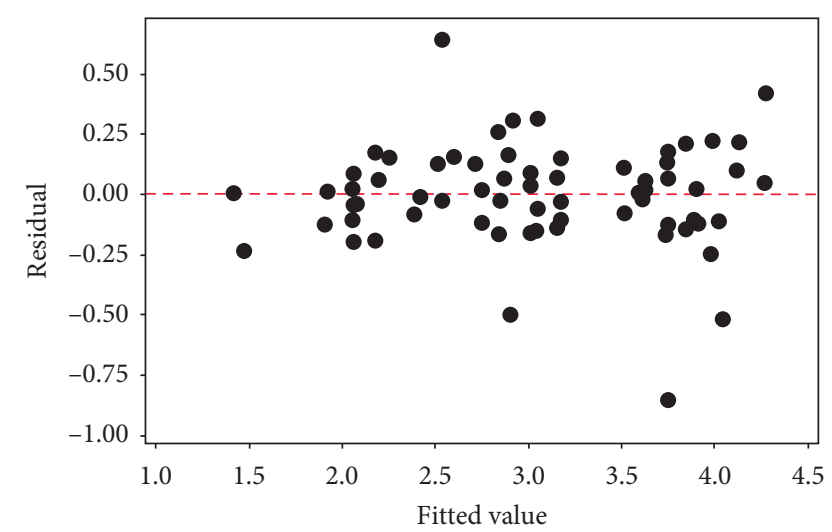

Figure 1: The residual distribution diagram for the best fitted model of Rhizophora mucronata.

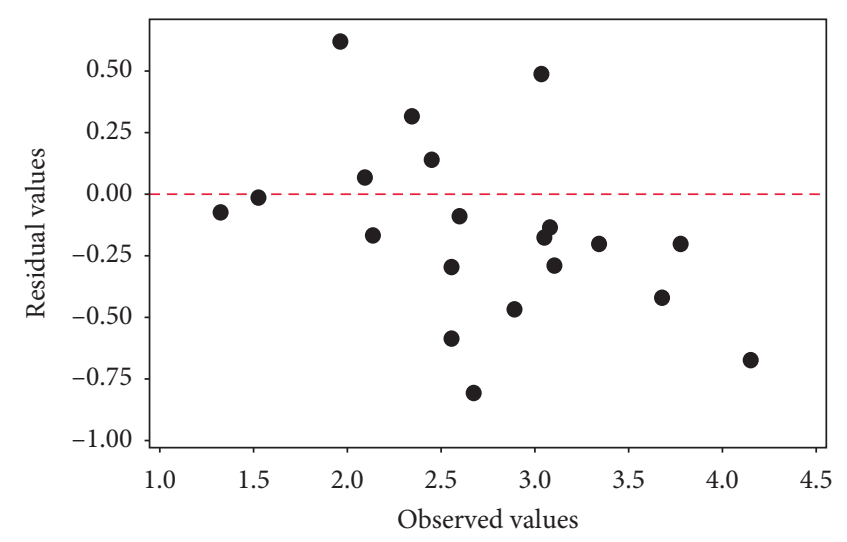

FIgURE 2: The residual diagram of residual versus actual values for validation of the best fitted model for Rhizophora mucronata.

Tree allometry is an important tool for estimating tree weight from independent variables such as trunk diameter, tree height, crown height, total height that are easily measurable in the field. The basic concept of allometric relationships is that the growth rate of one or more measurements of the tree is proportional to that of other parameters [22]. Most of these allometric equations are used for the biomass related studies in terrestrial forest ecosystems. However, few studies have used tree allometric modelling to determine the above ground biomass of mangrove trees in some regions of the world [22-27].

Determination of the stem carbon content of individual species is very important and can play a key role when assessing 
TABLE 5: Measured and predicted stem carbon content of Rhizophora mucronata.

\begin{tabular}{lcc}
\hline Measured stem carbon content $(\mathrm{kg})$ & Predicted stem carbon content $(\mathrm{kg})$ & $p$ value \\
\hline $2.53 \pm 0.76^{\mathrm{a}}$ & $2.49 \pm 0.67^{\mathrm{a}}$ & 0.731 \\
$(1.3-3.6)$ & $(1.3-4.3)$ & 0.73 \\
\hline
\end{tabular}

The data are presented as mean \pm standard deviation. The values within parentheses indicate the range of variation of the measured and predicted stem carbon content. ${ }^{\mathrm{a}}$ Measured and predicted stem carbon content of Rhizophora mucronata at $95 \%$ level of significance. $p>0.05$ indicates that there is no significant difference in the actual stem carbon content and the predicted stem carbon content from the developed model at $95 \%$ level of significance.

the carbon sequestration capacity of the ecosystems. The actively growing trees can store more carbon in their stem. This carbon is fixed by photosynthesis and comparatively high carbon content can be stored in the stem of the trees compared to the leaves. As trees mature, they sequester less carbon but gain the capacity to store carbon in their stems [28-30]. Therefore, it is very important to measure the carbon content of the tree stems, in order to estimate the role of a particular tree species in removal of excessive carbon dioxide from the atmosphere. However, use of destructive methods for this purpose is not advisable as they can disrupt the balance of the carbon removal process. Previous studies conducted in this part of the country to assess the mangrove carbon sequestration capacity have used destructive methods [31, 32]. The present study can be considered as the initial attempt to use a nondestructive method to construct an allometric equation to predict the stem carbon content of Rhizophora mucronata in a tropical conserved mangrove forest. Therefore, it is recommended to extend this allometric equation development method to estimate the stem carbon content of other common tropical mangrove species in order to get an accurate estimate on the contribution of tropical mangrove stem carbon storage capacity for mitigation of global warming.

\section{Conclusion}

The present study identifies that the allometric model, Ln $C=-2.403+2.247 \mathrm{Ln} \mathrm{DBH}$ as the best fit and practical model to estimate the stem carbon content of Rhizophora mucronata. The stem carbon content can be easily estimated from this model by using an easily measurable tree parameter. This is a non-destructive method and it is environmentally friendly as it does not require the tree to be removed from its natural environment. Furthermore, the results of the present study identifies that the Rhizophora mucronata as a suitable species to be used in mangrove replantation programs as it has the maximum carbon storage capacity when the trees are at a $\mathrm{DBH}$ range of $12-14 \mathrm{~cm}$. Findings of the present study can be extended to estimate the functional capacities carbon sequestration by other Sri Lankan mangroves, and therefore encourage rational decision making on conservation and management of mangrove areas for their ecological services including their carbon sequestration capacity and influence to mitigate predicted climatic changes.

\section{Data Availability}

The raw data of the study are available upon request from the corresponding author.

\section{Conflicts of Interest}

The authors declare that there are no conflicts of interest regarding the publication of this article.

\section{References}

[1] P. B. Tomlinson, Biogeography. The Botany of Mangroves, Cambridge University Press, New York, NY, USA, 1986.

[2] C. Giri, E. Ochieng, L. L. Tieszen et al., "Status and distribution of mangrove forests of the world using earth observation satellite data," Global Ecology and Biogeography, vol. 20, no. 1, pp. 154-159, 2011.

[3] W. Giesen, S. Wulffraat, M. Zieren, and L. Scholten, "Mangrove guidebook for southeast Asia," Food and Agriculture Organization of the United Nations, Regional Office for Asia and the Pacific, Food and Agriculture Organization, Rome, Italy, 2006.

[4] A. E. Schwarzbach and R. E. Ricklefs, "Systematic affinities of Rhizophoraceae and Anisophylleaceae, and intergeneric relationships within Rhizophoraceae, based on chloroplast DNA, nuclear ribosomal DNA, and morphology," American Journal of Botany, vol. 87, no. 4, pp. 547-564, 2000.

[5] Grin, "Rhizophora mucronata information from NPGS/ GRIN," Taxonomy for Plants, National Germplasm Resources Laboratory USDA, ARS, National Genetic Resources Program, Beltsville, MD, USA, 2006.

[6] J. Kumar, M. E. Vijey Kumar, K. B. Ranjanna et al., "Ecological benefits of mangrove," Life Sciences Leaflets, vol. 48, pp. 8588, 2014.

[7] N. H. Tri, W. N. Adger, and P. M. Kelly, "Natural resource management in mitigating climate impacts: the example of mangrove restoration in Vietnam," Global Environmental Change, vol. 8, pp. 49-61, 1998.

[8] D. M. Alongi, "Mangrove-microbe-soil relations," in In Macro- and Microorganisms in Marine Sediments, E. Kristensen, R. R. Haese, and J. E. Kostka, Eds., pp. 85-103, American Geophysical Union, Washington, DC, USA, 2005.

[9] D. M. Alongi and P. Dixon, "Mangrove primary production and above-and below-ground biomass in Sawi Bay, southern Thailand," Phuket Marine Biological Center Research Bulletin, vol. 22, pp. 31-38, 2000.

[10] D. M. Alongi, "Mangrove forests: resilience, protection from tsunamis, and responses to global climate change," Estuarine, Coastal and Shelf Science, vol. 76, no. 1, pp. 1-13, 2008.

[11] K. Dhanwantri, P. Sharma, S. Mehta, and P. Prakash, "Carbon sequestration, its methods and significance," Environmental Sustainability: Concepts, Principles, Evidences and Innovations, vol. 151, no. 2, pp. 151-157, 2014.

[12] D. Murdiyarso, J. Purbopuspito, J. B. Kauffman et al., “The potential of Indonesian mangrove forests for global climate change mitigation," Nature Climate Change, vol. 5, no. 12, pp. 1089-1092, 2015. 
[13] B. S. Sabin, "Relationship between allometric variables and biomass in Western Juniper (Juniperus Occidentalis)," M.S. thesis, Oregon State University, Corvallis, Oregon, 2008.

[14] G. H. Guendehou and A. Lehtonen, Guidance for Tree Measurement in Tropical Forest Ecosystems Using Non-Destructive Sampling to Develop Stem Biomass and Volume Models, Finnish Forest Research Institute, Kuala Lumpur, Malaysia, 2014.

[15] S. M. C. U. P. Subasinghe and A. M. R. Haripriya, "Prediction of stem biomass of Pinus caribaea growing in the low country wet zone of Sri Lanka," Journal of Tropical Forestry and Environment, vol. 4, no. 1, pp. 40-49, 2014.

[16] M. Köhl, P. R. Neupane, and N. Lotfiomran, "The impact of tree age on biomass growth and carbon accumulation capacity: a retrospective analysis using tree ring data of three tropical tree species grown in natural forests of Suriname," PLoS One, vol. 12, no. 8, Article ID e0181187, 2017.

[17] M. G. Ryan and B. J. Yoder, "Hydraulic limits to tree height and tree growth," Bioscience, vol. 47, no. 4, pp. 235-242, 1997.

[18] M. G. Ryan, D. Binkley, and J. H. Fownes, "Age-related decline in forest productivity: pattern and process," in Advances in Ecological Research, vol. 27, pp. 213-262, Academic Press, Cambridge, MA, USA, 1997.

[19] E. V. Carey, A. Sala, R. Keane, and R. M. Callaway, "Are old forests underestimated as global carbon sinks?" Global Change Biology, vol. 7, no. 4, pp. 339-344, 2001.

[20] S. Delzon, M. Sartore, R. Burlett, R. Dewar, and D. Loustau, "Hydraulic responses to height growth in maritime pine trees," Plant, Cell and Environment, vol. 27, no. 9, pp. 1077-1087, 2004.

[21] N. L. Stephenson, A. J. Das, R. Condit et al., "Rate of tree carbon accumulation increases continuously with tree size," Nature, vol. 507, no. 7490, pp. 90-93, 2014.

[22] A. Komiyama, V. Jintana, T. Sangtiean, and S. Kato, "A common allometric equation for predicting stem weight of mangroves growing in secondary forests," Ecological Research, vol. 17, no. 3, pp. 415-418, 2002.

[23] B. Christensen, "Biomass and primary production of Rhizophora apiculata $\mathrm{Bl}$ in a mangrove in southern Thailand," Aquatic Botany, vol. 4, pp. 43-52, 1978.

[24] S. Tamai, T. Nakasuga, R. Tabuchi, and K. Ogino, "Standing biomass of mangrove forests in southern Thailand," Journal of the Japanese Forestry Society, vol. 68, no. 9, pp. 384-388, 1986.

[25] J. W. Day, W. H. Conner, F. Ley-Lou, R. H. Day, and A. M. Navarro, "The productivity and composition of mangrove forests, Laguna de Términos, Mexico," Aquatic Botany, vol. 27, no. 3, pp. 267-284, 1987.

[26] R. R. Twilley, R. Zimmerman, L. Solorzano et al., “The importance of mangroves in sustaining fisheries and controlling water quality in coastal ecosystems," Interim Report, U.S. Agency for International Development, Program in Science and Technology Cooperation, Washington, DC, USA, 1990.

[27] M. L. G. Soares and Y. Schaeffer-Novelli, "Above-ground biomass of mangrove species. I. analysis of models," Estuarine, Coastal and Shelf Science, vol. 65, no. 1-2, pp. 1-18, 2005.

[28] J. H. Brown and G. B. West, "Scaling in biology," in The Origin of Universal Scaling Laws in Biology, G. B. West, J. H. Brown, and B. J. Enquist, Eds., pp. 87-112, Oxford University Press, Oxford, UK, 2000.

[29] B. Lippke, J. Wilson, J. Meil, and A. M. Taylor, "Characterizing the importance of carbon stored in wood products," Wood and Fiber Science, vol. 42, pp. 5-14, 2010.
[30] C. A. Price, J. S. Weitz, V. M. Savage et al., "Testing the metabolic theory of ecology," Ecology Letters, vol. 15, no. 12, pp. 1465-1474, 2012.

[31] M. D. Amarasinghe and S. Balasubramaniam, "Net primary productivity of two mangrove forest stands on the northwestern coast of Sri Lanka," in The Ecology of Mangrove and Related Ecosystems, pp. 37-47, Springer, Dordrecht, Netherlands, 1992.

[32] M. A. D. Umayangani and K. A. R. S. Perera, "Contribution of vegetation structure on carbon assimilation capacity of mangrove ecosystem: a case study from negombo estuary, Sri Lanka," International Journal of Marine Science, vol. 7, no. 46, pp. 439-446, 2017. 